\title{
Ortak Çalışma Olgusu ve Ofis Kafeler
}

\author{
Büşra TUNÇ ${ }^{1}$, Kutlu SEVINÇ KAYIHAN ${ }^{2 \star}$
}

Öz

Teknolojinin, yaşam şartlarının, güç unsurlarının, çalışma biçimlerinin ve daha pek çok farklı olgunun değişmesiyle ofis mimarisi zaman içerisinde seri bir dönüşüm geçirmiştir. 21. yüzyıl başlarında ortaya çıkan yeni iş tanımları nedeniyle 'istediğin yerde istediğin zaman çalışmak' eğilimi ve kurumdan bağımsız bir ofis olgusu gündeme gelmiştir. Ortak bir mekânı paylaşan bireylerin belirgin olmayan sürelerde ve zaman aralıklarında çalışabilmelerine imkân sunan ve yeni nesil çalışma biçimi olarak gündeme gelen ortak çalışma (co-working) kavramı, özellikle bağımsız çalışan bireyler tarafından yoğun biçimde benimsenmiştir. Bu eğilimin bir sonucu olarak enformel çalışma mekânları çeşitli düzeylerde toplu kullanımların gerçekleştiği kamusal alanlara yayılarak çeşitlenmiştir. Bu çalışmada öncelikle ortak çalışma (co-working) olgusunun ortaya çıkışı ve gelişiminden bahsedilmiş, İstanbul'un Kadıköy ve Karaköy gibi merkezi semtlerinde yaygın olarak gözlenen "kafede çalışma" olgusu belirli mekânlar üzerinden değerlendirilmiştir. Kafelerde yer bulan enformel çalışma alanları gözlem, görüşme ve anket yöntemleri kullanılarak kullanıcı profilleri, kullanıcı ihtiyaçları, tercih edilme nedenleri ile mimari tasarımları ve kullanım biçimleri üzerinden irdelenmiş, bazı sonuç ve önerilere yer verilmiştir.

Anahtar Kelimeler: Çalışma mekânı, Ortak çalışma, Ofis kafe

\section{The Concept of "co-working" and Office Cafe}

\begin{abstract}
Office architecture has undergone a series of transformations over time with the changes to technology, living conditions, power elements, working patterns and many other things. At the beginning of the 21st century, due to new job descriptions, there was a tendency to 'work whenever and wherever you want' and brought, an office concept independent from the institution, to the agenda. The concept of "co-working" as a new generation of work which allows individuals who share a common place to work in unspecific times and time periods, has been heavily adopted by independent workers. As a result of this tendency, informal working spaces have been diversified by spreading to public areas where mass use takes place at various levels. In this study, firstly the emergence and development of the "co-working" phenomenon was mentioned, and the "study in the cafe" phenomenon commonly observed in the central districts of Istanbul such as Kadıköy and Karaköy was evaluated in certain places. The informal work areas found in cafes were examined through user profiles, user needs, preference reasons, architectural designs and usage patterns by using observation, interview and questionnaire methods and some results and suggestions were given.
\end{abstract}

Keywords: Work space, Co-working, Office cafe

\footnotetext{
${ }^{1}$ Gebze Teknik Üniversitesi, Fen Bilimleri Enstitüsü, Mimarlık Anabilim Dalı.

${ }^{2}$ Gebze Teknik Üniversitesi, Mimarlık Fakültesi, Mimarlık Bölümü.

*ilgili Yazar / Corresponding Author: sevinc@gtu.edu.tr

Gönderim Tarihi: 12.09 .2018

Kabul Tarihi: 26.12 .2018
} 


\section{Giriş}

Günümüzde yaşantımızın büyük bir bölümünü işgal eden çalışma hayatı, zamanımızın önemli bir bölümünü ofislerde geçirmemize neden olmaktadır. Son dönemlerde ofis dışında çalışmayı gerektiren yeni iş tanımlarının ortaya çıkmasıyla, ofis yapılarının değişen koşullara çoğu zaman uyum sağlayamadığı görülmüştür. Özellikle ofis dışında bağımsız çalışanların, mobil çalışanların, girişimcilerin, küçük işletmelerin ve kurumsal firmaların intiyaçlarına alışılagelmiş geleneksel ofis kullanımları yeterli gelmemektedir. $\mathrm{Bu}$ intiyaçlar yan fonksiyonlar olarak farklı yapı işlevlerinin altında kendini göstermeye başlamıştır. Yaşanan bu tablonun sonucunda ortak çalışma (co-working) kavramı ortaya çıkmış, bu yeni nesil çalışma biçimi özellikle 2005'den günümüze kadar olan süreçte oldukça benimsenmiştir.

Türkiye'nin en kalabalık kenti olan İstanbul'un nüfusu 15 milyon 29 bin 231 dir (TUIK, 2018). İstanbul'un bu denli kalabalık ve iş trafiğinin en yoğun yaşandığı kent olmasıyla doğru orantılı olarak, aynı zamanda ortak çalışma kültürünün doğduğu ve yaygınlaştığı örnek kent olması nedeniyle saha araştırması için İstanbul seçilmiştir. İstanbul'da insanların ortak çalışma biçimini yoğun olarak kullandığı çok sayıda kafe bulunması sebebiyle de Kadıköy ve Karaköy semtleri örneklem olarak belirlenmiştir.

Kafelerin planları yerinde gözlemler sonucunda şematik olarak oluşturulmuş, kullanıcılar ve/veya kafe sahipleri tarafından belirlenen çalışma alanları şematik planlara işlenmiştir. Bu mekânlarda yer alan enformel çalışma alanları gözlem, görüşme ve anket yöntemleri kullanılarak analiz edilmiştir. Bu alanların içerdiği çalışma fonksiyonunun kullanıcı talep ve intiyaçlarına ne derece cevap verebildiği karşılaştırmalı olarak saptanmaya çalışıımıştır.

\section{Ortak Çalışma (Co-Workıng) OIgusunun Gelişimi ve Ofis-Kafeler}

Ortak çalışma (co-working) kavramı kelime anlamı olarak, dijital devrim ve temposu gitgide artan şehir yaşamı nedeniyle çalışma kültürünün dönüşümünün bir sonucu olarak, ortak bir mekânı paylaşan insanlara belirsiz sürelerde ve zaman aralıklarında çalışabilme imkânı sunan yeni nesil çalışma biçimi olarak tanımlanmaktadır (Selman, 2016, s.n.y). Aslında bu çalışma biçimi genel anlamda serbest çalışanlar (freelancer), evden çalışanlar (home-office), girişimciler (start-up) ve küçük ölçekli şirket sahipleri gibi esnek bir çalışma düzenine sahip, belli bir çalışma yerine intiyaç duymayan ve/veya tamamen bağımsız çalışan bireyler için üretilmiş bir kavramdır. Ortak çalışma aynı zamanda bu çalışma gruplarının sosyal anlamda biraraya gelmesini, birlikte çalışırken ortaya çıkan sinerjiyi ve bazı değerleri paylaşmalarını da sağlamaktadır (Foertsch, 2011, s.n.y).

Son zamanlarda kafelerde, özellikle ücretsiz internet erişimine sahip olanlarda; prize en yakın masada konumlanmış bilgisayarı ile saatlerce vakit geçiren öğrencilere, ofislerinden sıkılan profesyonellere ya da freelancerlara rastlamak oldukça olağan bir durum haline gelmiştir. Bu çalışma düzeni kafe sahipleri için ya da müşterileri için her zaman ideal değildir. Özellikle de sınırlı oturma yerleri olan küçük kafelerde problem daha yoğun hissedilmektedir. Hatta bazı kafeler yoğun saatlerde tek bir içecekle tüm günü aynı masada geçiren kullanıcılar için zaman sınırlamaları dahi getirmişlerdir. Bunun sonucunda kafe sahipleri çözümü, mekânlarını ofis-kafe, kitap-kafe, ofiskütüphane gibi konseptler ile yeniden tasarlayarak çok daha esnek ve çeşitlendirilebilir mekânlar haline getirmekte bulmuşlardır. Bununla birlikte, konsept kafeler sayıca giderek artarak, bir kafenin üretkenliği ve ekipmanı ile rahatığını birleştiren bir melez modele sahip olmuştur, neticede de kafeler ve çalışma alanları arasındaki çizgi 
bulanıklaşmaya başlamıştır. (Johnston Taylor, 2016, s.n.y)

1999 yılında Bernie Dekoven tarafından ortaya atılan ortak çalışma 'co-working' konsepti, geleneksel çalışma şeklinin sorgulanmasının en somut sonuçlarından biri olarak öne çıkmaktadır (Sundsted, Jones and Bacigalupo, 2009, s.n.y). 2005 yılında bir yazılım geliştirme uzmanı olan Brad Neuberg tarafından "sosyal olmayan" iş merkezlerine ve evlerdeki üretken olmayan iş hayatına tepki olarak yeniden gündeme getirilmiş ve günümüze kadar ortak çalışma hareketi (co-working movement) olarak varlığını korumuş, popülaritesini artırarak kullanıcılarını çoğaltmıştır (Zeytun, 2014, s.n.y).

Makalenin devamında incelenecek olan ulusal örneklerden önce, yurtdışındaki ortak çalışma amaçlı kullanılan kafeler bağlamında, günümüzde de halen faaliyette olan Virjinya'daki CoWork Cafe iyi bir örnek olacaktır. Ortak çalışma biçimi anlayışı ile tasarlanmış bir mekân olmakla birlikte kullanıcılarına anlık kullanımlar için toplu, bireysel, resmi gayriresmi çalışma alanları sunmaktadır. Kullanıcılar alanı kendileri kontrol edebilmekte, intiyaç dâhilinde kendi minimal tasarımlarını yapabilmektedirler.

Diğer bir örnek olan San Francisco'da 2013 yılında açılan ve halen hizmet veren Workshop Café'de ise müşteriler mekânda harcadıkları vakit miktarınca ücret ödemekte ve bununla birlikte sınırsız interent imkânından da faydalanabilmektedirler. "Esneklik" olgusunu çalışma mekânında yaşatmak üzere tasarlanan bu kafenin mobil uygulaması ile kullanıcılar kendilerine anlık sandalye bile edinebilmekteler. Aynı zamanda farklı çoğunluktaki grupları ağırlayabilen farklı ölçülerde esnek çalışma grupları ve sunum alanları da mekânda mevcuttur.
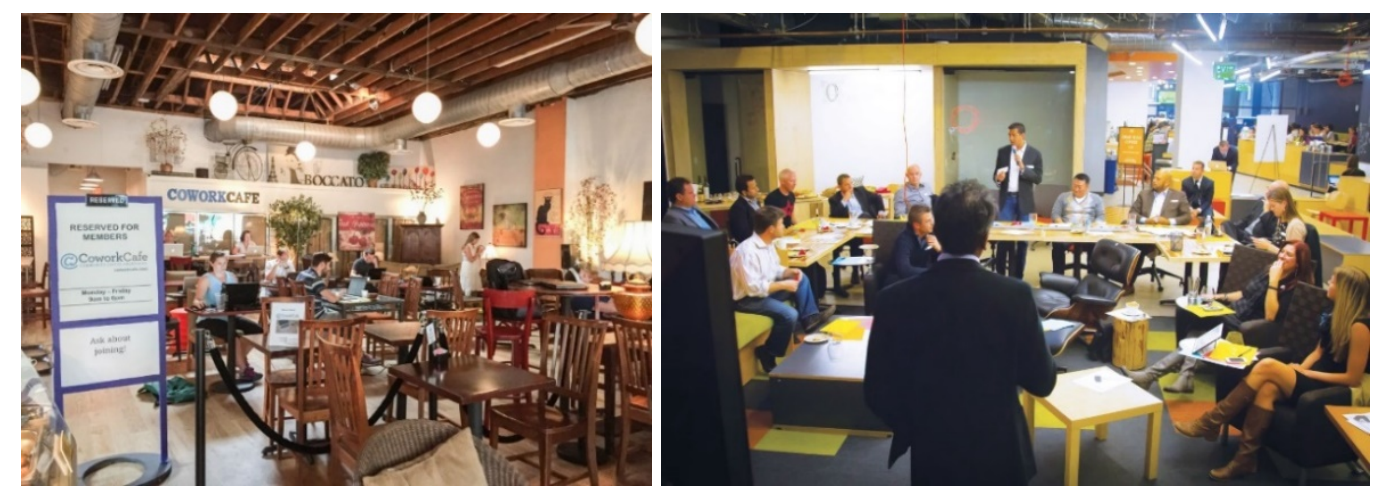

Resim 1. CoworkCafé -Arlington, Virginia [7],Resim 2. Workshop Café-San Francisco [8].

Malezya, Penang'da bulunan Habitat Coworking Cafe belli üyelik imkânları ile birlikte, ortak çalışma alanları, kafeterya, toplantı odası, galeri, etkinlik alanı gibi hizmetler sunmaktadır. Ortak çalışma anlayışını önceki örneklerden daha profesyonelce mekâna yansıtabilmiş olan bu kafe kullanıcılarına sağladığı sınırsız internet erişimi, ofis malzemeleri, sosyal etkinlikler, çevre edinme gibi birçok artı da katmaktadır. Aynı zamanda yine bu olgunluğa erieşbilmiş bir diğer kafe örneği de Los Angeles de bulunan Verve Coffee olarak verilebilir. Kapalı, yarı açık, açık mekân seçenekleri ve farklı boyutlardaki oturma grupları ile kullanıcılarına esnek alanlar yaratmayı amaçlamaktadır. 


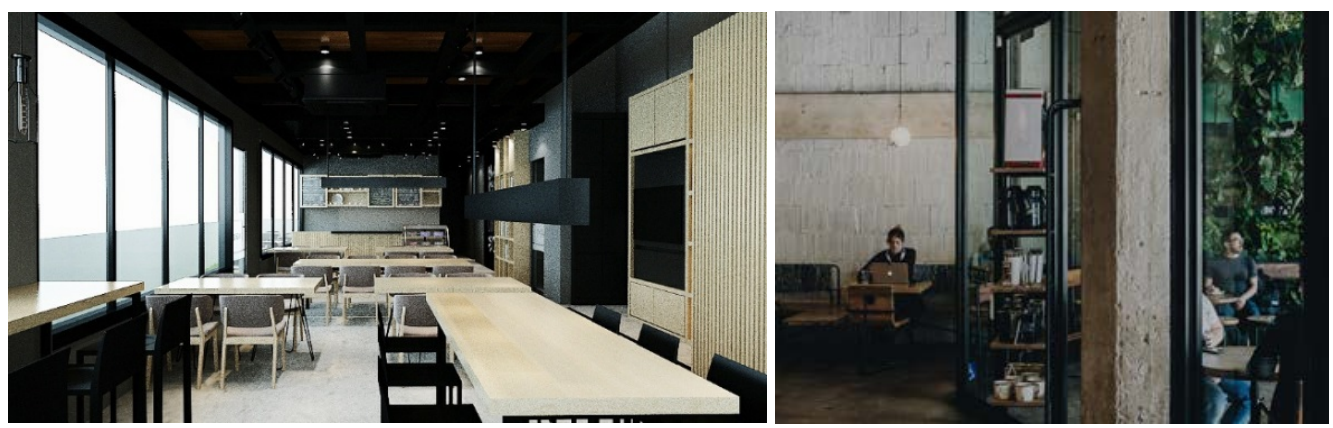

Resim 3. Habitat Coworking Cafe, Malezya [9],Resim 4. Verve Coffee -Los Angeles [10].

Yurt dışında bulunan kafe örnekleri evrilmeye çok daha erken yıllarda başlamış olmasına rağmen ülkemizde kafelerin reel olarak çalışma amaçlı kullanılmasına rağmen ortak çalışma (coworking) kültürü halen daha çoğu kişi tarafından bilinmemektedir. Ülkemizdeki örnekler genelde varolanı iyileştirme, dönüştürme ile kendini gösterirken bahsedilen yurtdışı örneklerinde de görülebileceği gibi kafe sahipleri kullanıcıların ne istediğini bilmekte, ona göre esnek mekânlar sunmakta ve bu işi profesyonelce yapmaya çalışmaktadırlar.

Kafelerde çalışma kültürünün oldukça eski bir mazisi olmasına rağmen, bir kısım kafe sahipleri yeni nesil çalışma biçimi olan ortak çalışma akımına uyum sağlayıp, kendilerini yenileyerek kullanıcıların intiyaçları doğrultusunda mekânlarını ona göre şekillendirebilmişlerdir. Fakat bir kısım kafe sahipleri ise uzun süreler kafelerde çalışarak yer işgal eden kullanıcıları engelleyebilmek adına internet erişiminde kesintilere gitme gibi bazı önlemler dahi almışlardır. Günümüzde de görülmektedir ki, kullanıcının intiyaçlarını önemseyen mekânlar kullanıcılar tarafından oldukça benimsenmektedir.

'İstediğin yerde, istediğin zaman çalışma' fikri insanları daha esnek çalışma mekânları edinmeye itmiş, bu düşünceyi eyleme geçirme noktasında ortak çalışma alanı olarak kafelerin seçildiği gözlenmiştir. Genellikle sabit bir iş tanımı olmayan çalışanların kullandığı mekânlar haline gelen kafeler; kolay ulaşılabilirlikleri, sağladıkları yemeiçme avantajları, kahve kültürüne yatkın çalışan kesime hitap edebilmesi, toplumla birlikte çalışma ve sosyalleşme ihtiyacını karşılayabilmeleri gibi nedenlerle -bazı dezavantajlarına rağmen (ses, ışık, değişken konum, kısıtlı hizmet saatleri, güvenlik eksikliği, ekonomik zorluklar vb.)- çalışma amaçlı tercih edilmektedirler.

\subsection{Kadıköy örnekleri}

\subsubsection{Kafe Akademi 1971}

Kadıköy Bahariye Caddesi'ne çok yakın bir konumda yer alan kitap-kafenin hafta içi/hafta sonu kullanım yoğunluğu fazladır. Kafenin genel müşteri kullanımı zemin katta, bireysel ve grup çalışmalarına hitap eden, daha sessiz ve gözden uzak kısmı bodrum katta yer almaktadır (Resim 5-6 - 7) (Şekil 1-2). 


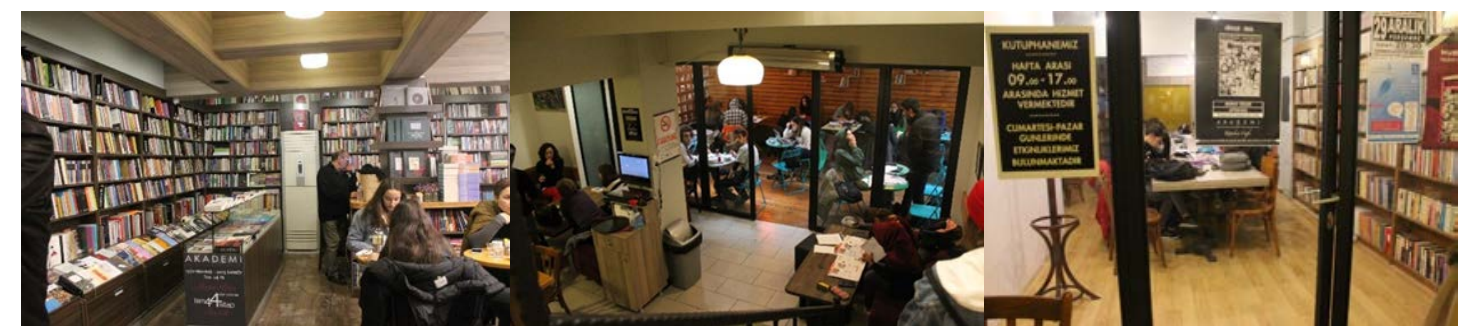

Resim 5. Genel kullanım, Resim 6. İç bahçe, Resim 7. Mini kütüphane (Tunç, 2016).

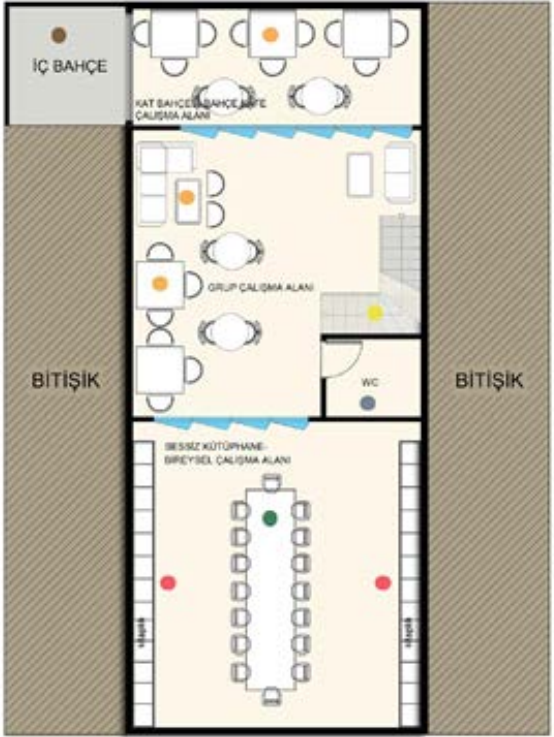

BODRUM KAT PLANI

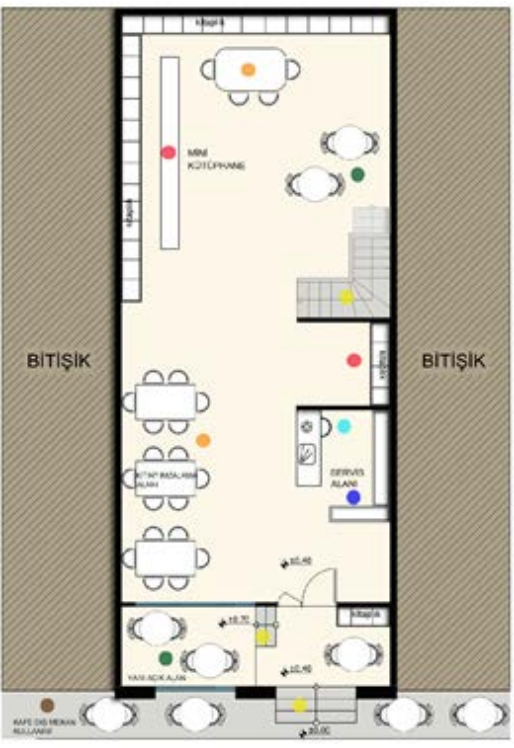

ZEMIN KAT PLANI

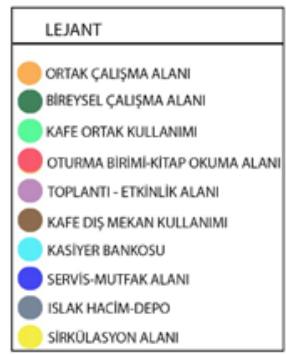

Şekil 1. - 2. Akademi 1971 kat planları (Tunç, 2016).

\subsubsection{Cherrybean Kafe}

Moda'da sakin bir sokakta bulunan kitap-kafe genellikle hafta sonu yoğun olarak kullanılmasına karşın, hafta içi de bağımsız çalışanlar için uğrak bir mekân olma özelliği taşır. Kafenin genel müşteri kullanımı zemin katta, bireysel ve grup çalışmalarına hitap eden daha sessiz ve gözden uzak kısmı bodrum kattadır (Resim 8, $9,10)$ (Şekil $3-4)$.

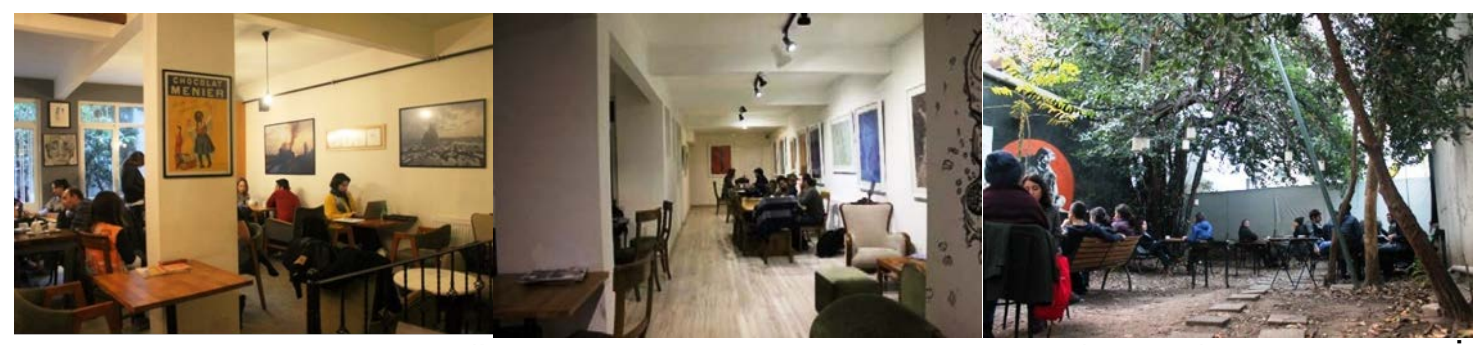

Resim 8. Zemin kat genel kullanımı, Resim 9. Bodrum kat ortak çalışma alanı, Resim 10. İç bahçe (Tunç, 2016). 


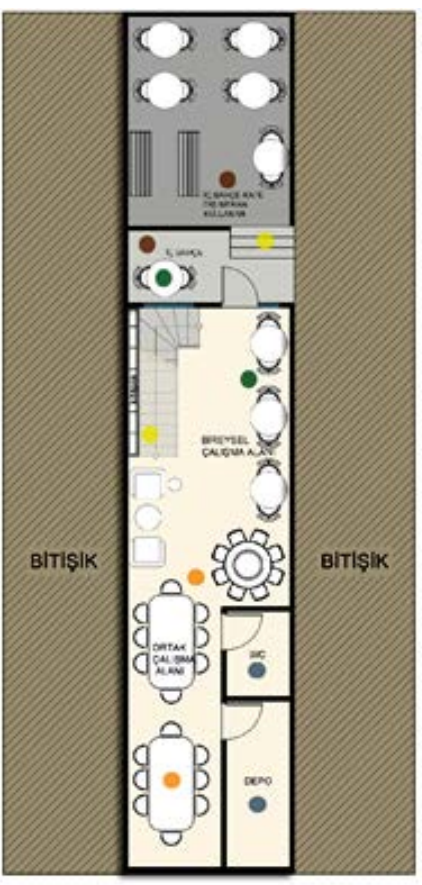

BODRUM KAT PLAN

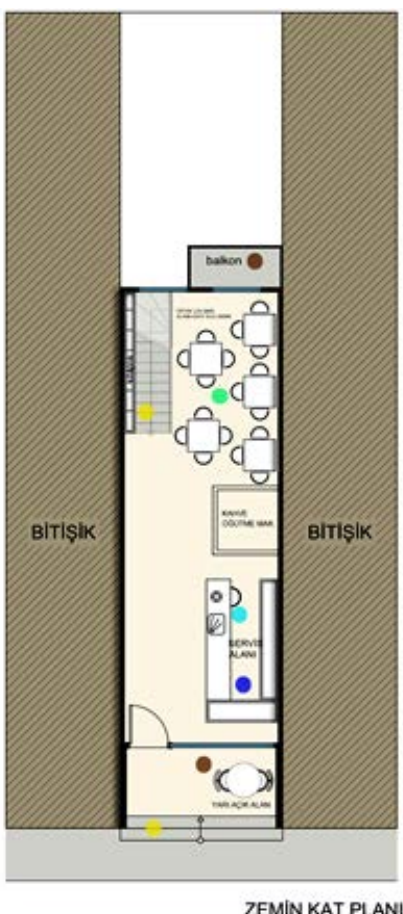

ZEMIN KAT PLAN

\begin{tabular}{|l|}
\hline LEJANT \\
\hline ORTAK ÇALIȘMA ALANI \\
BIREYSEL ÇALISMA ALANI \\
KAFE ORTAK KULLANIMI \\
OTURMA BIRIMI-KITAP OKUMA ALANI \\
TOPLANTI - ETKINLIK ALANI \\
KAFE DIS MEKAN KULLANIMI \\
KASIYYR BANKOSU \\
SERVIS-MUTFAK ALANI \\
ISLAK HACIM-DEPO \\
SIRKOLASYON ALANI
\end{tabular}

Şekil 3. - 4. Cherrybean Kafe Kat Planları (Tunç, 2016).

\subsubsection{Page Kafe}

Kadıköy Moda'da işlek bir sokakta yer alan kitap kafe özellikle hafta sonu yoğun bir mekândır. Kafenin dış mekân kullanımı iç mekân kullanımından daha geniş bir yer tutmaktadır. Hareketli dış mekân genel kafe kullanımına, sessiz iç mekân ise ortak ve bireysel çalışmaya hitap etmektedir (Resim 11, 12, 13) (Şekil 5).

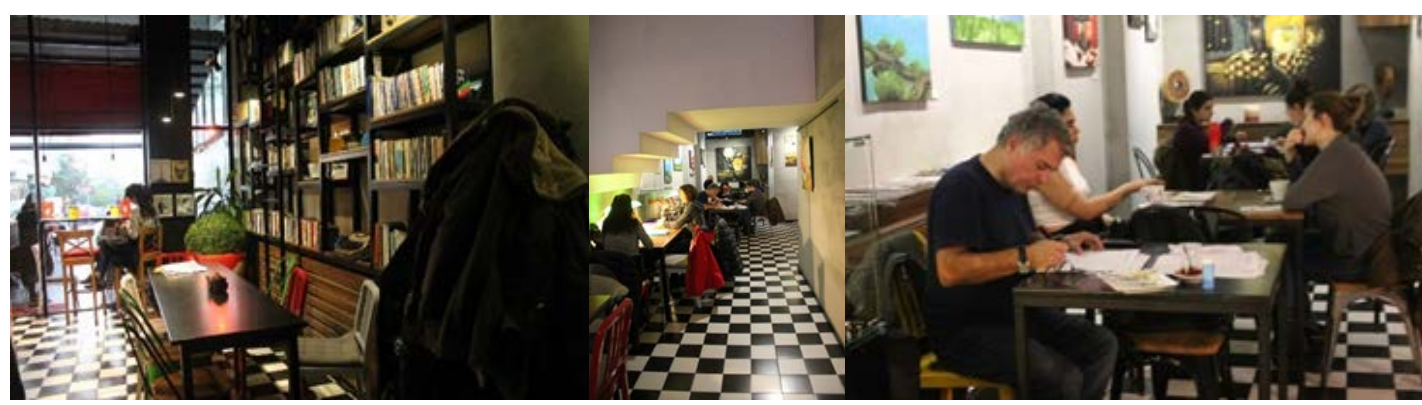

Resim 11. - 12. - 13. Ortak ve bireysel çalışma alanları (Tunç, 2016). 


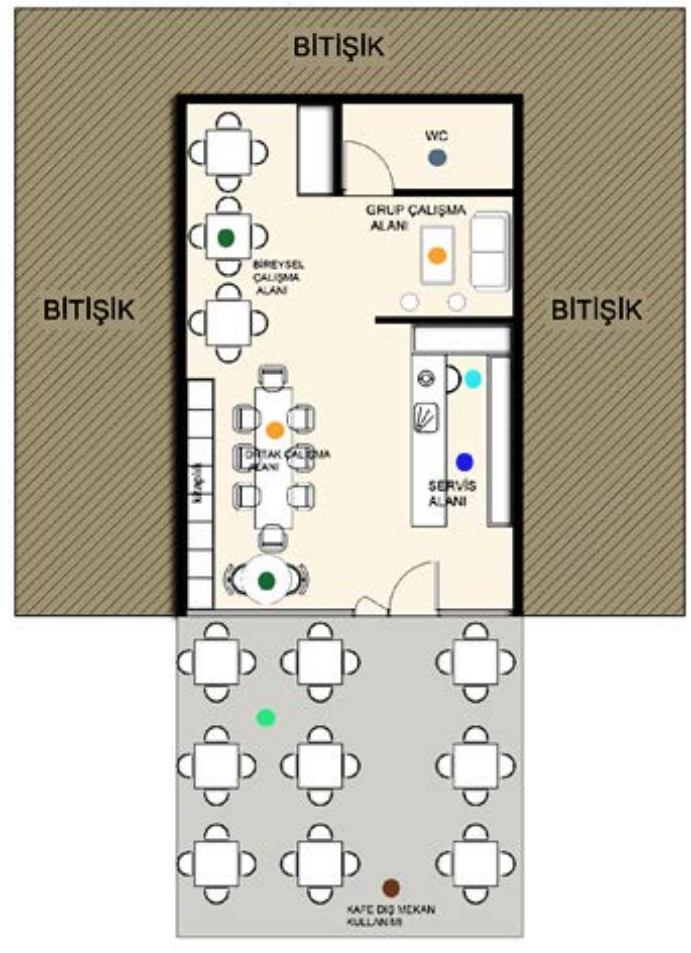

ZEMIN KAT PLANI

\begin{tabular}{|l|}
\hline LEJANT \\
\hline ORTAK ÇALISMA ALANI \\
BIREYSEL ÇALIȘMA ALANI \\
KAFE ORTAK KULLANIMI \\
OTURMA BIRIMI-KITAP OKUMA ALANII \\
TOPLANTI - ETKINLIK ALANI \\
KAFE DIŞ MEKAN KULLANIMI \\
KASIYER BANKOSU \\
SERVIS-MUTFAK ALANI \\
ISLAK HACIM-DEPO \\
SIRKULLASYON ALANI \\
\hline
\end{tabular}

Şekil 5. Page Kafe, Zemin Kat Planı (Tunç, 2016).

\subsubsection{Tasarım Bookshop Kafe}

Mimar Emre Tibet'e ait Bahariye Caddesi'ndeki mekân, aynı zamanda Tasarım Dergisi'nin resmi dağıtımının yapıldığı kitap-kafedir. Kafeyi çoğunlukla öğrenciler ve serbest çalışan mimarlar tercih etmektedir. Kafenin dış mekân kullanımı olmamakla birlikte, kot farklarından yararlanılarak farklı mekân tanımları ve ayrışmaları gerçekleştirilmiştir (Resim 14, 15, 16) (Şekil 6 - 7).

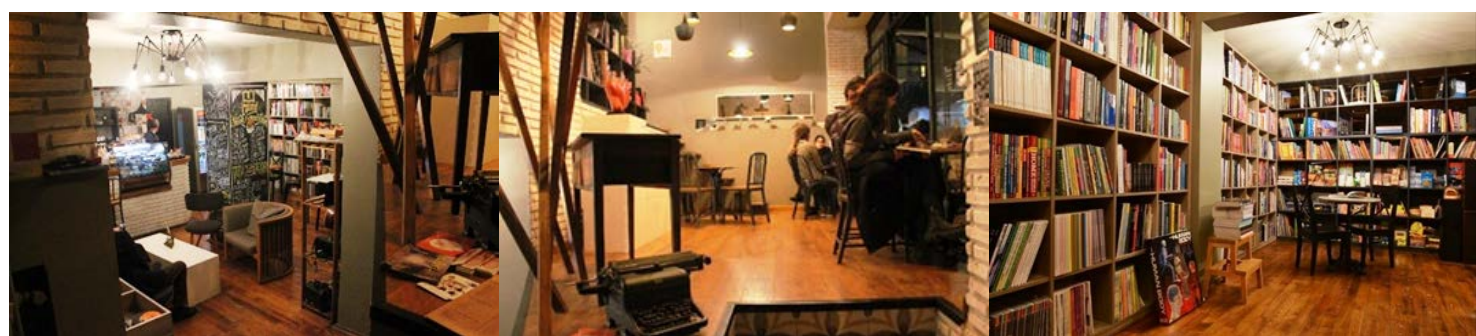

Resim 14. Giriş, Resim 15. Bireysel Çalışma Alanı, Resim 16. Ortak Çalışma Alanı-Mini Kütüphane (Tunç, 2016). 

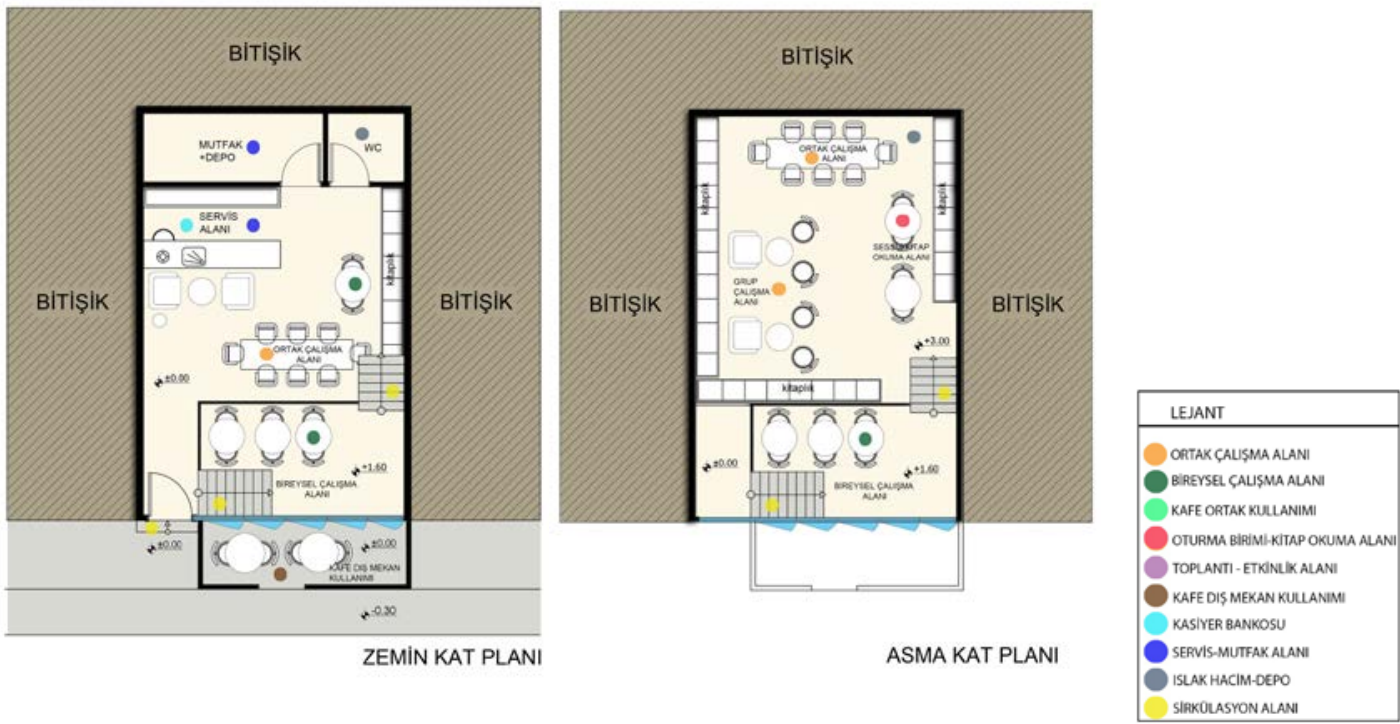

Şekil 6. - 7. Tasarım Bookshop Kafe, Kat Planları (Tunç, 2016).

\subsubsection{Starbucks Kafe}

Moda'da, hem hafta içi hem hafta sonu oldukça yoğun bir kafedir. Dış mekân kullanımı iç mekân kullanımına oranla daha fazladır. Bireysel ve ortak çalışma alanları kafenin iç kısımlarındadır (Resim 17, 18). İç mekânda gürültü ve hareketlilik oldukça fazladır. Bağımsız çalışanlara özel, bölücü elemanlarla genel kullanımdan ayrılmış bir paylaşımlı alan da mevcuttur (Şekil 8).

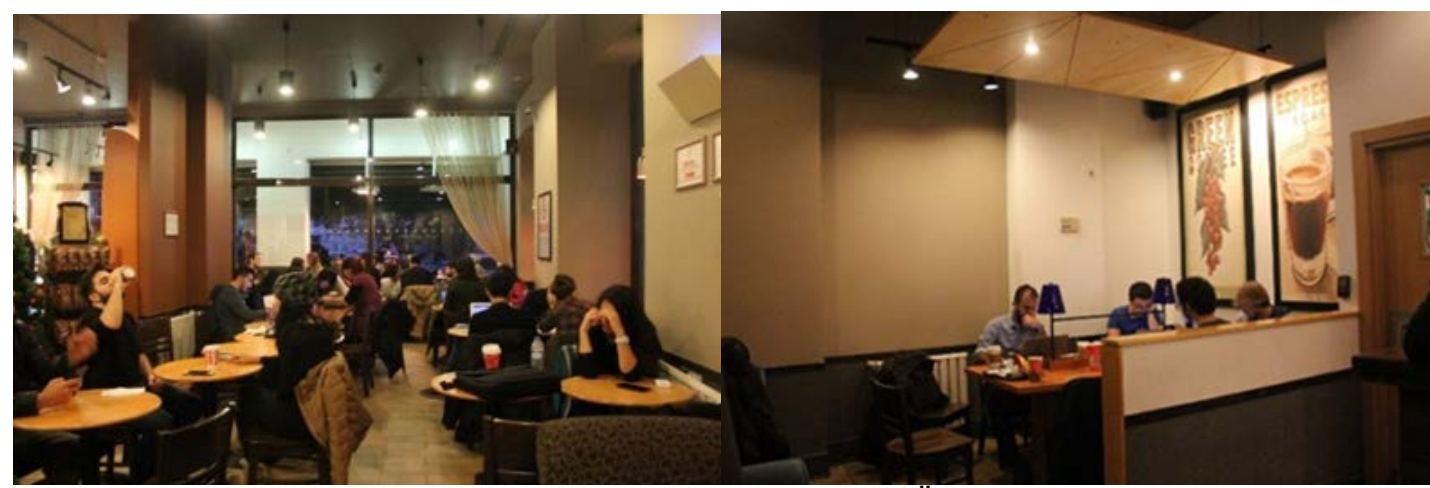

Resim 17. Kafe genel kullanımı ve çalışma alanı, Resim 18. Özelleşmiş paylaşımlı çalışma alanı (Tunç, 2016). 


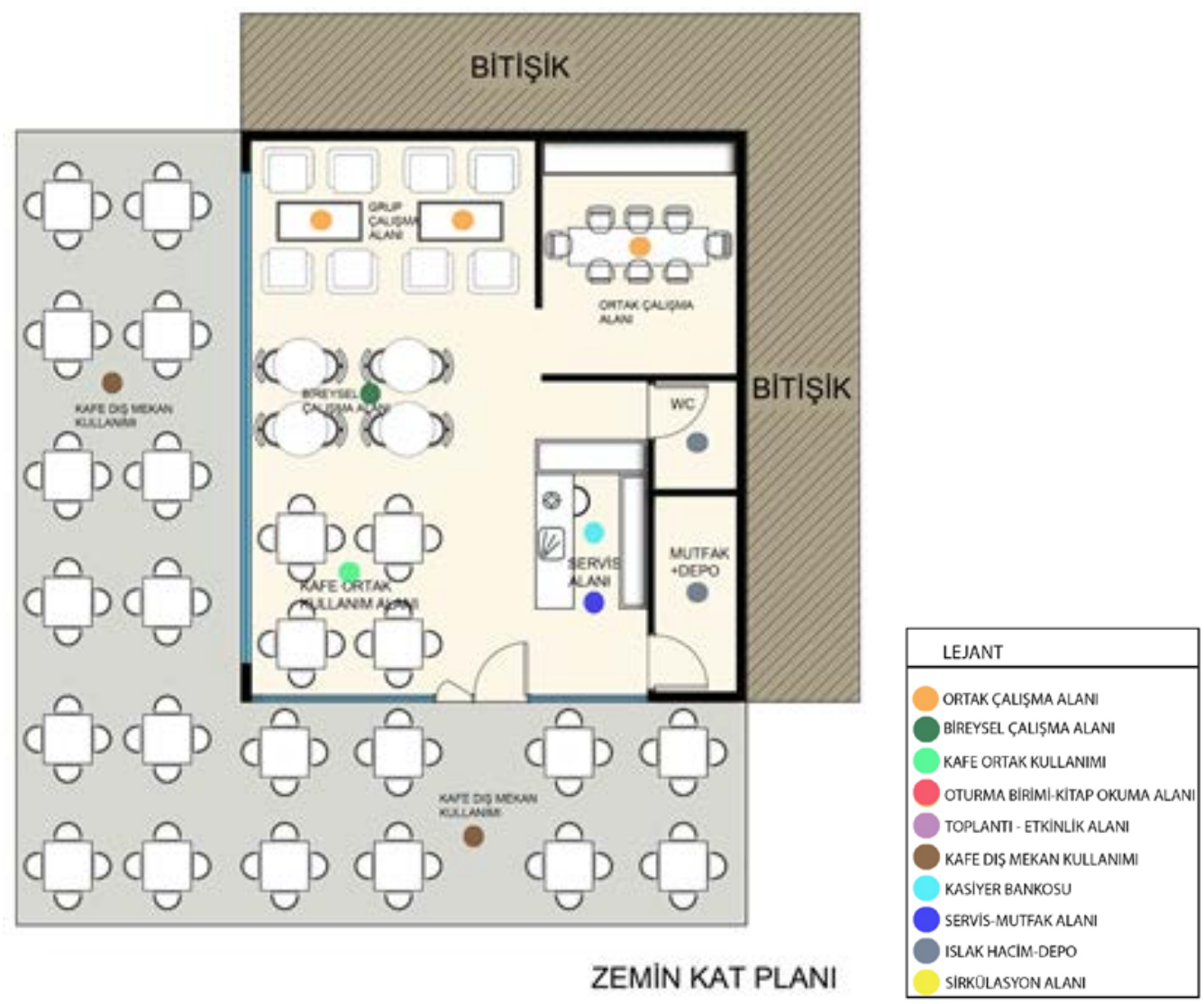

Şekil 8. Starbucks Kafe, Zemin Kat Planı (Tunç, 2016).

\subsection{Karaköy örnekleri}

\subsubsection{Dem Kafe}

Kemankeş Caddesi'nde bulunan mekân çay evi konseptiyle bir butik kafe özelliği taşır. Tarihi bir binada, yeni bir iç mekân düzenlemesiyle açılan kafenin dış mekân kullanımı çok yoğun olmamakla birlikte iç mekânda da kot farklarıyla farklı türde çalışma mekânları tanımlanmıştır (Resim 19, 20) (Şekil 9).

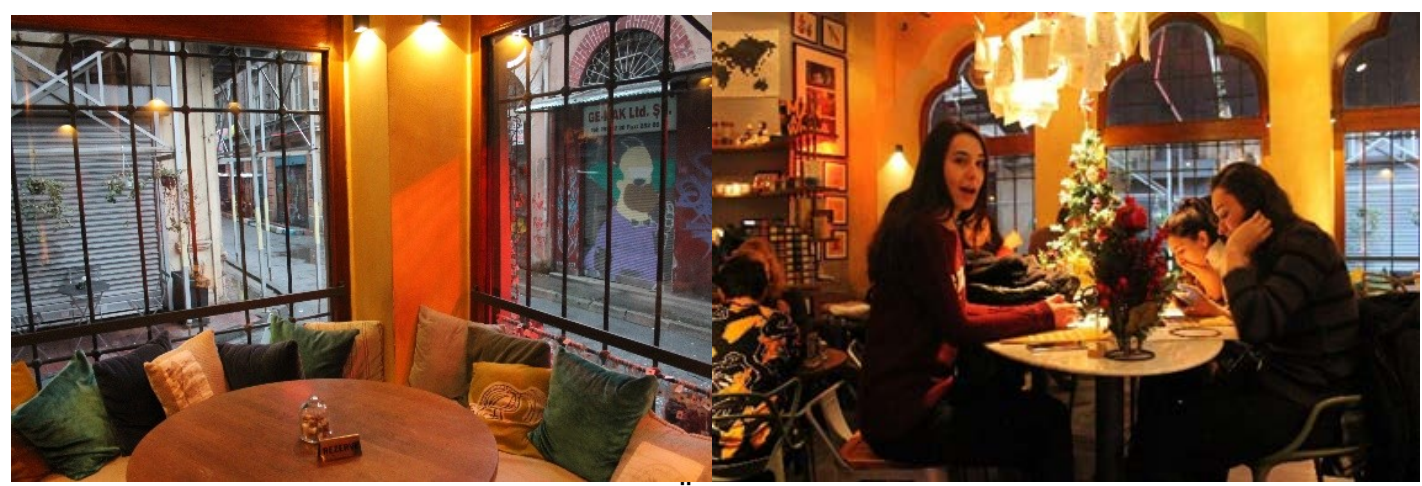

Resim 19. Bireysel Çalışma Alanı (Pencere Önü Sedir), Resim 20. Ortak çalışma alanı (Tunç, 2016). 


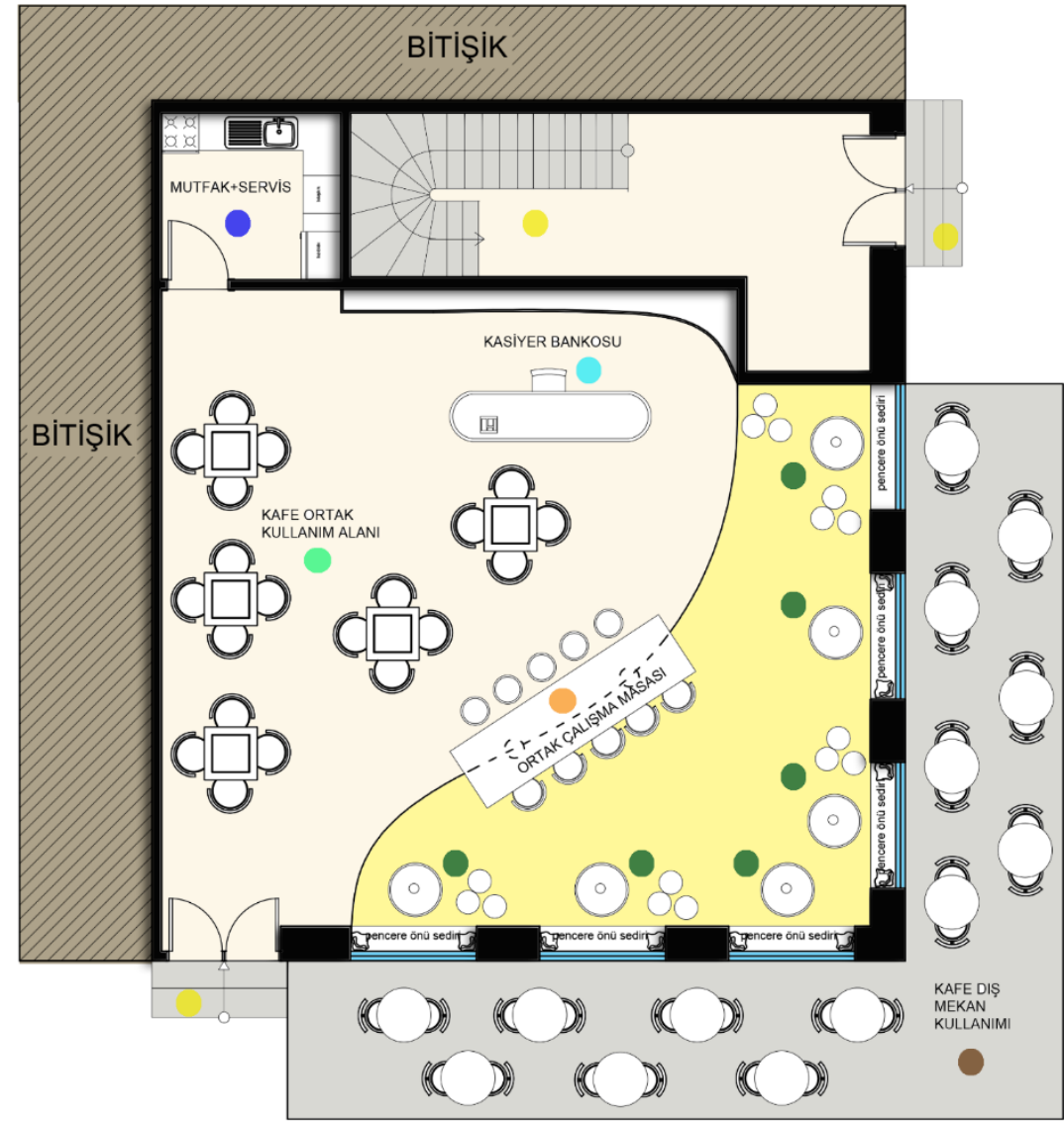

ZEMIN KAT PLANI

\begin{tabular}{|l|}
\hline LEJANT \\
\hline ORTAK ÇALISMA ALANI \\
BIREYSEL ÇALSMMA ALANI \\
KAFE ORTAK KULLANIMI \\
OTURMA BIRIMI-KITAP OKUMA ALANI \\
TOPLANTI- ETKINLIK ALANI \\
KAFE DIS MEKAN KULLANIMI \\
KASIYYR BANKOSU \\
SERVIS-MUTFAKALANI \\
ISLAK HACIM-DEPO \\
SIRKOLLASYON ALANI \\
\hline
\end{tabular}

Şekil 9. Dem Kafe, Zemin Kat Planı (Tunç, 2016).

\subsubsection{Han Kafe}

Kemankeş Caddesi' nde bulunan Dem Kafe'nin üst katında bulunan mekân, kitap kafe konseptiyle oluşturulmuş bir butik kafe özelliği taşır. Tarihi bir binada, yeni bir iç mekân düzenlemesiyle açılan kafenin bireysel çalışma alanı, ortak kullanıma oranla daha fazladır. Dem Kafe'deki gibi pencere önündeki sedir kısımları bireysel çalışma alanı olarak özelleşmiştir (Resim 21, 22) (Şekil 10).

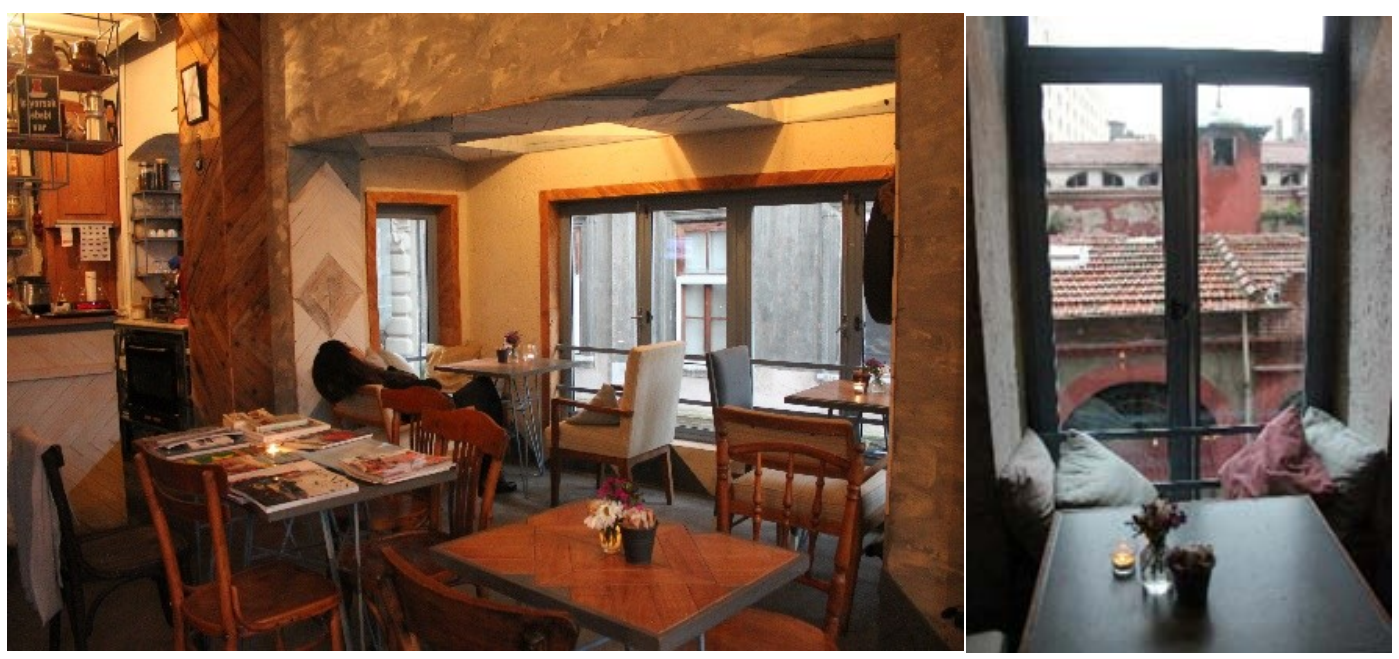


Resim 21. Ortak çalışma alanı, Resim 22. Bireysel çalışma alanı (Tunç, 2016).

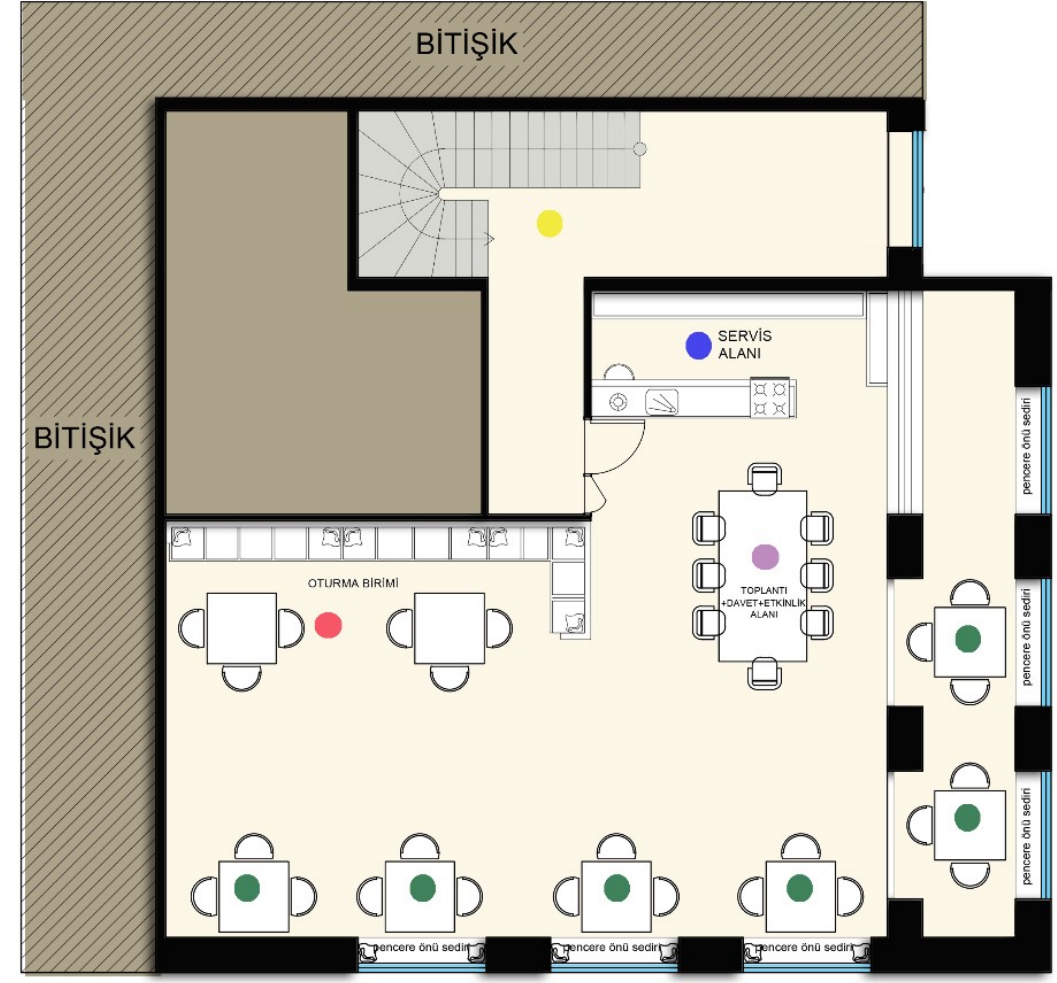

1.NORMAL KAT PLANI

\begin{tabular}{|l|}
\hline LEJANT \\
\hline ORTAK CGULSMA ALANI \\
BIREYSEL ÇALSMA ALANI \\
KAFE ORTAK KULLANIMI \\
OTURMA BIFIMI-KITAP OKUMA ALANI \\
TOPLANTI- ETKINLIK ALANI \\
KAFE DIS MEKAN KULLANIMII \\
KASIYYR BANKOSU \\
SERVIS-MUTFAKALANI \\
ISLAKHACIM-DEPO \\
SIRKOLASTON ALANI \\
\hline
\end{tabular}

Şekil 10. Han Kafe, 1.Normal Kat Planı (Tunç, 2016).

\subsubsection{Dandin Kafe}

Kemankeş Caddesi'nde bulunan Dandin Kafe diğer işlek kafelere nazaran hafta sonu bile yoğunluğu fazla olmayan bir kafedir. Kafenin hitap ettiği kesim bağımsız çalışanlar ve beyaz yakalı çalışanların öğle yemeği saatleridir. Kafede zemin kata genel kafe kullanımı ve bireysel çalışma alanları hakimken, asma katta ortak çalışma alanı olarak özel istek üzerine kullanıma açılan bir mekân bulunur (Resim 23 - 24) (Şekil 11 - 12).

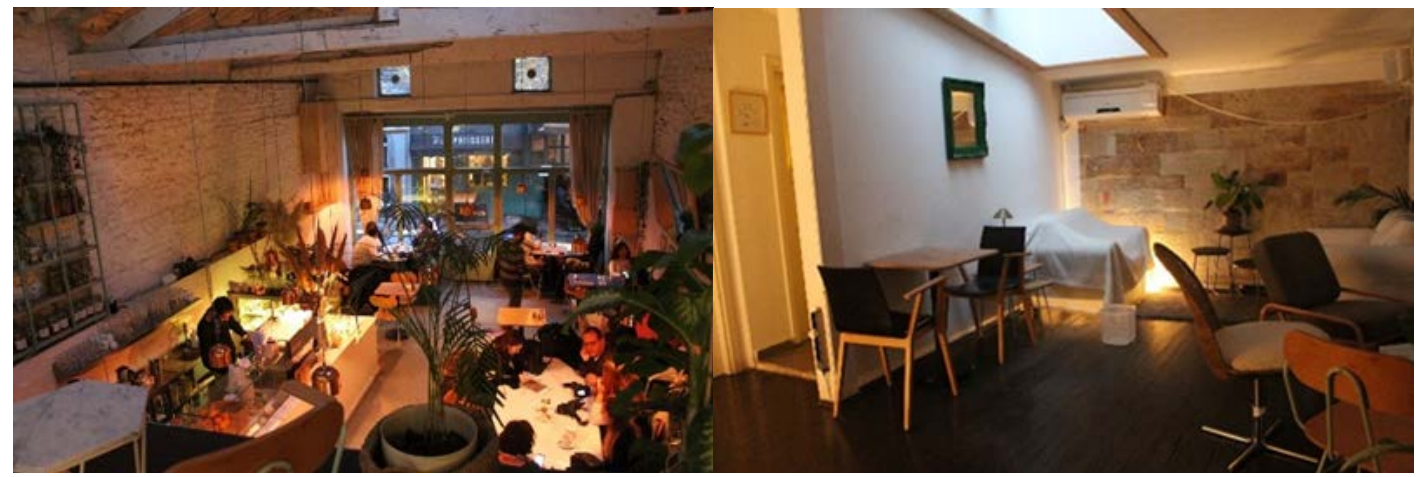

Resim 23. Kafe genel kullanımı, Resim 24. Asma katta yer alan ortak çalışma alanı (Tunç, 2016). 


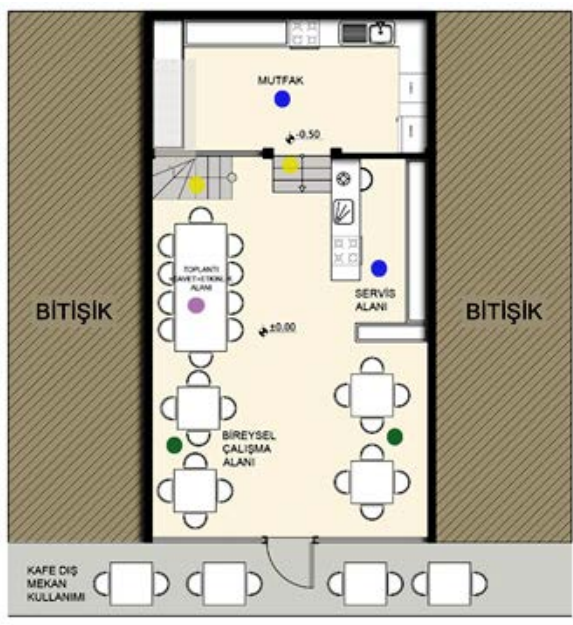

ZEMIN KAT PLANI

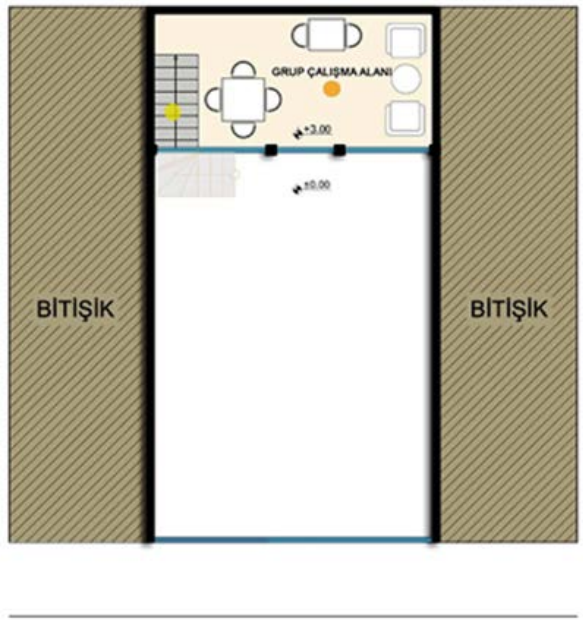

ASMA KAT PLANI

\begin{tabular}{|l|}
\hline LEJANT \\
\hline ORTAK ÇALSMMA ALANI \\
BIREYSEL ÇALSMA ALANI \\
KAFE ORTAK KULLANIMI \\
OTURMA BIRIIM-KITAP OKUMA ALANI \\
TOPLANTI - ETKINLIK ALANI \\
KAFE DIS MEKAN KULLANIMI \\
KASIYYRER BANKOSU \\
SERVIS-MUTFAK ALANI \\
ISLAK HACIM-DEPO \\
SIRKOLASYON ALANI
\end{tabular}

Şekil 11. - 12. Dandin Kafe, Kat Planları (Tunç, 2016).

\subsubsection{Filbooks Kafe}

Kemankeş Caddesi'nde bulunan Filbooks Kafe, sahiplerinin tasarımlarının satışını yaptıkları ve mini bir kütüphanesi olan bir kitap kafedir. Üç kattan oluşan kafe özellikle hafta sonu yoğun kullanılmaktadır. Zemin katında kafenin genel kullanım alanı ve mini bir kütüphane bulunmakta, 1. Normal katta daha sakin bir ortama sahip olan ortak çalışma mekânları, 2. normal katta ise yapılan etkinliğin tarzına göre biçimlendirilebilen bir toplantı alanı vardır (Resim 25, 26, 27) (Şekil 13 - 14 - 15).
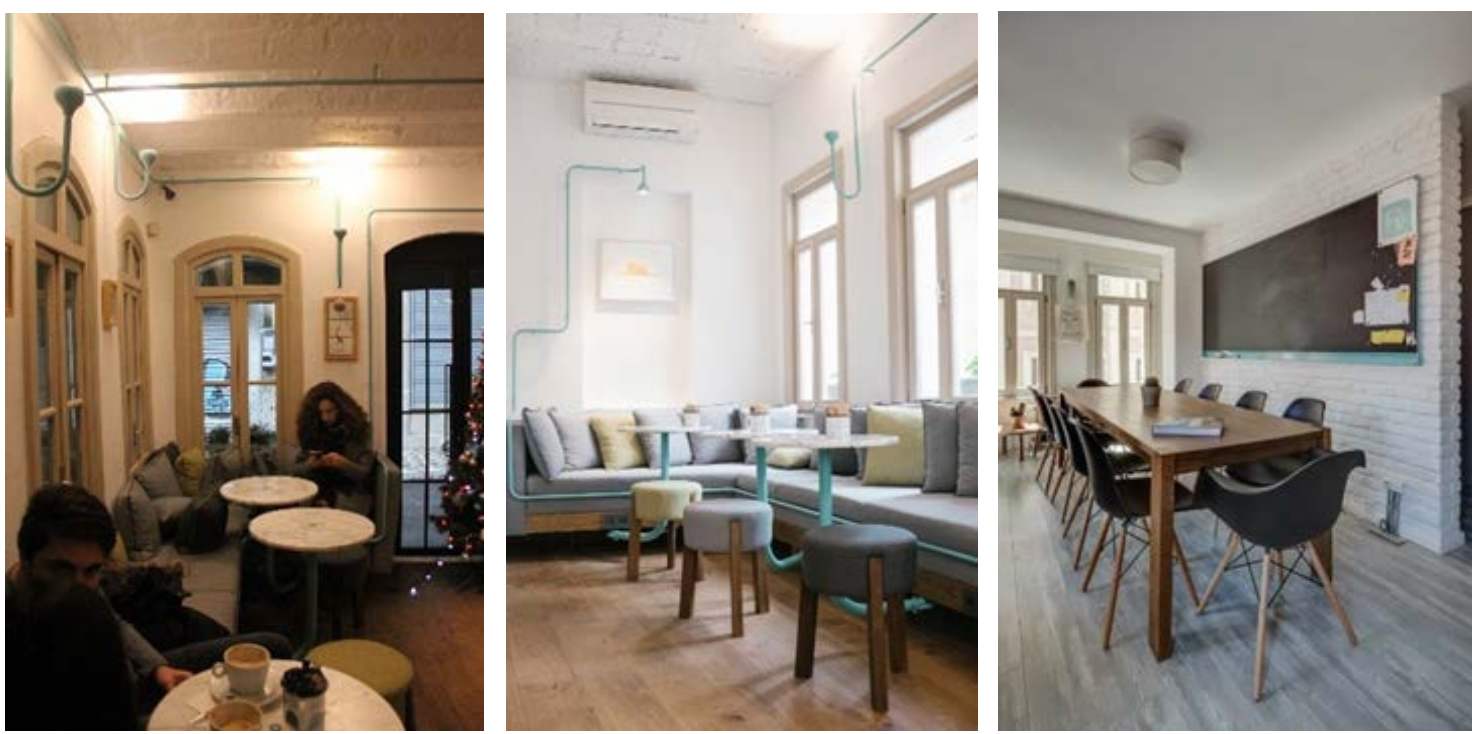

Resim 25. Genel kullanım, Resim 26. Ortak çalışma alanı (Tunç, 2016), Resim 27. Toplantı alanı [11]. 

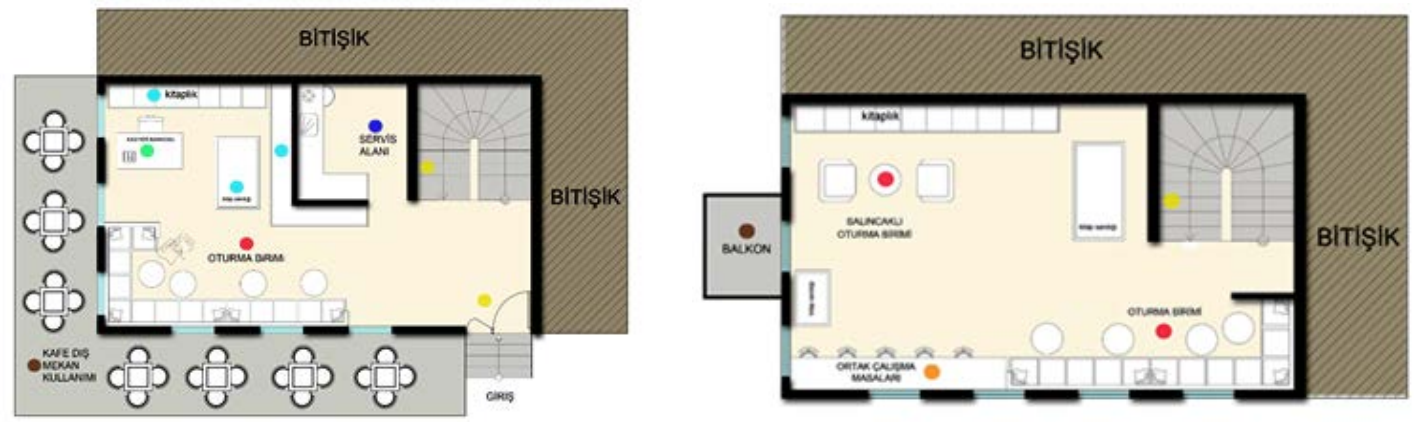

ZEMIN KAT PLANI

1.NORMAL KAT PLAN

Şekil 13. - 14. Filbooks Kafe, Zemin Kat, 1. Normal Kat Planı (Tunç, 2016).

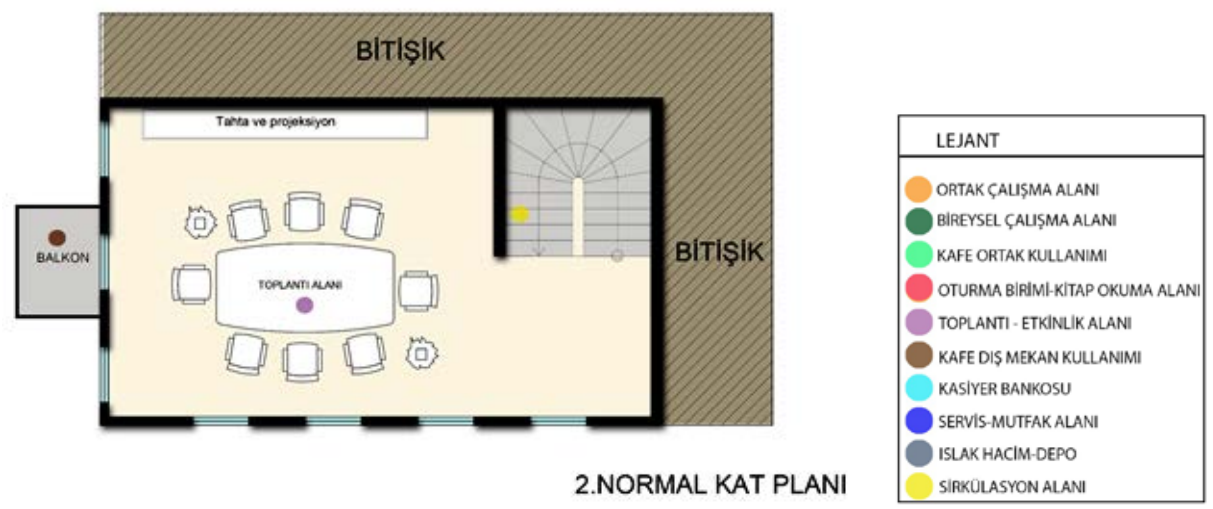

Şekil 15. Filbooks Kafe, 2.Normal Kat Planı (Tunç, 2016).

\subsubsection{Karabatak Kafe}

Kemankeş Caddesi'ndeki en popüler ve işlek kafedir. Mekân eski bir Ortodoks kilisesinin restore edilmesi ve butik bir kitap kafeye dönüştürülmesiyle oluşturulmuştur. İki kattan oluşan mekânın zemin katında genel kullanım alanı, bireysel çalışma alanları için özelleşmiş bölümler ve mini bir kütüphane bulunmaktadır. 1. katta daha sakin bir ortama sahip olan ortak çalışma mekânları ve toplantı alanı bulunmaktadır (Resim 28 29) (Şekil 16 - 17).

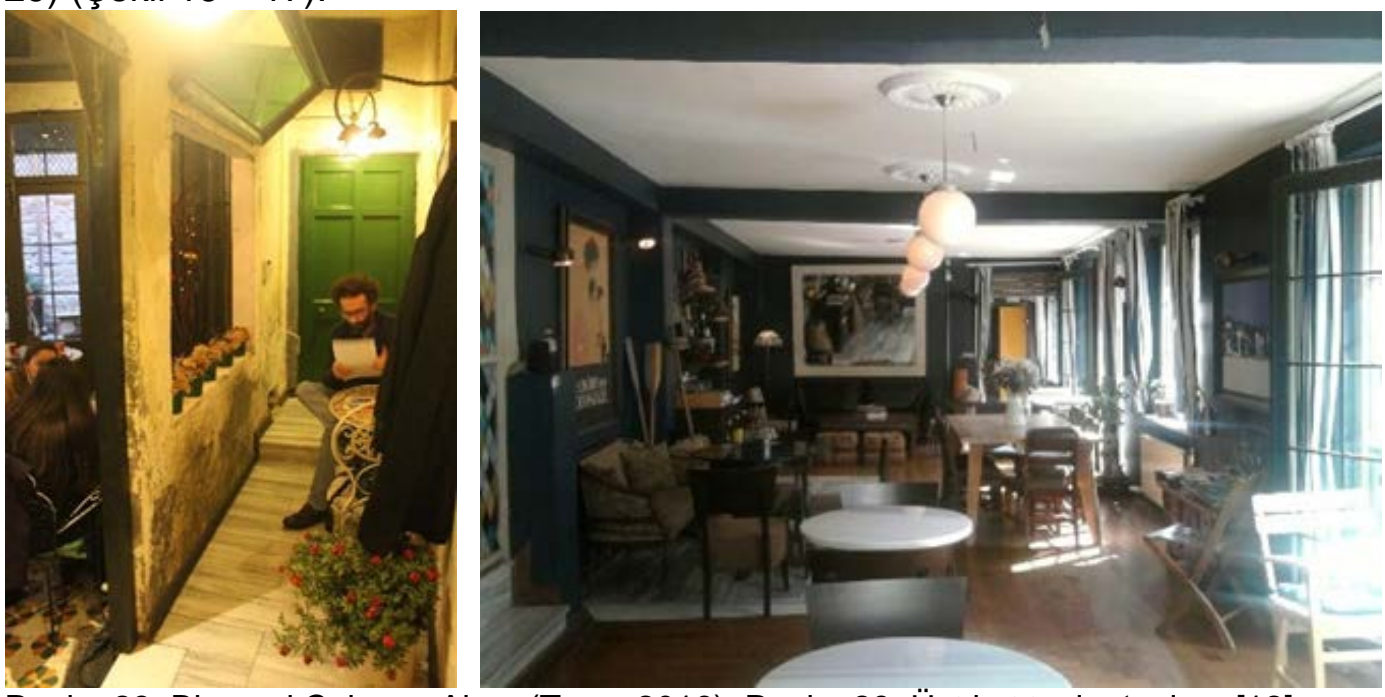

Resim 28. Bireysel Çalışma Alanı (Tunç, 2016), Resim 29. Üst kat toplantı alanı [12]. 

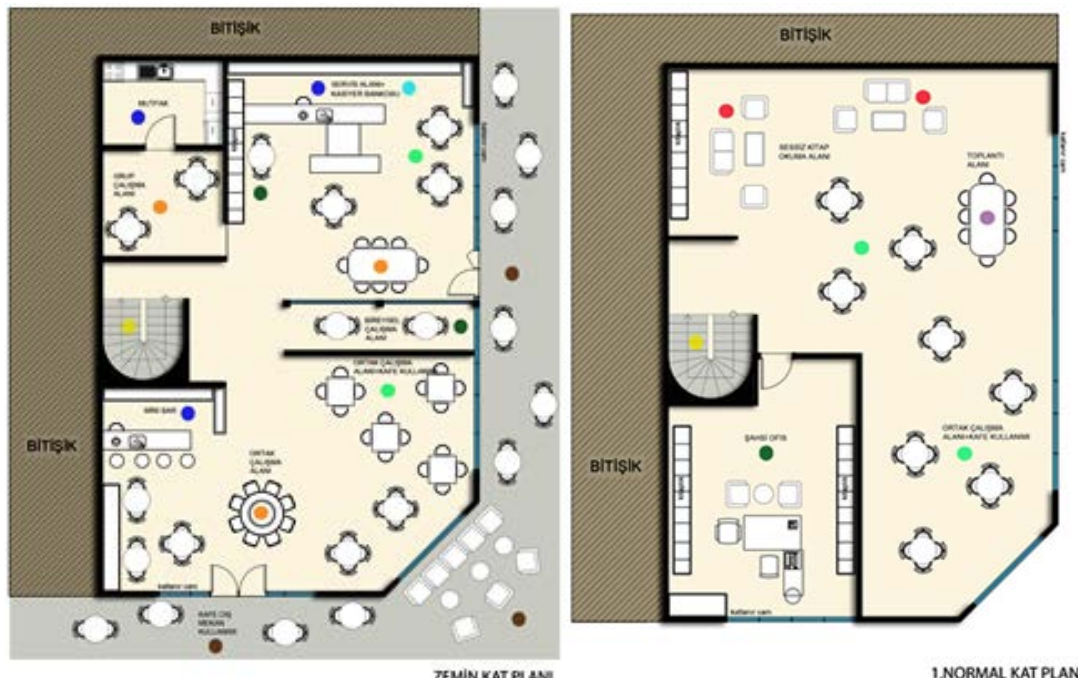

INORMAL KAT PLAN

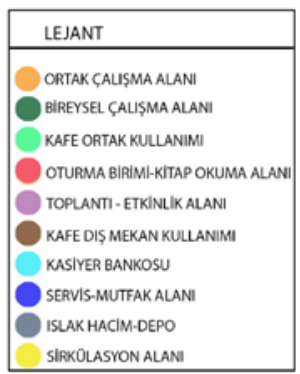

Şekil 16. - 17. Karabatak Kafe, Kat Planları (Tunç, 2016).

\section{Değerlendirme}

Ortak çalışma biçiminin popülerlik kazanmasıyla birlikte, kullanıcılar da kafede çalışmaya yönelik bir eğilim baş göstermiş ve bu tür mekânlar kendi içlerinde grup halinde ya da "birarada ama bireysel" çalışılabilen özelleşmiş alanlara ayrılmışlardır. Kafeler çalışma amaçlı kullanımlarıyla ilişkili çeşitli özellikleriyle Tablo 1'de karşılaştırılmıştır.

Tablo 1. Kafelerin genel özelliklerini gösteren tablo

\begin{tabular}{|c|c|c|c|c|c|c|c|c|}
\hline KAFE & Ulaşılabilirlik & Yoğunluk & $\begin{array}{l}\text { Dış mekan } \\
\text { kullanımı }\end{array}$ & Kitaplık & $\begin{array}{l}\text { Ortak } \\
\text { Çalışma } \\
\text { Alanı }\end{array}$ & $\begin{array}{l}\text { Bireysel } \\
\text { Çalışma } \\
\text { Alanı }\end{array}$ & $\begin{array}{l}\text { Etkinlik } \\
\text { Alanı }\end{array}$ & $\begin{array}{l}\text { Baskın } \\
\text { Kullanıcı }\end{array}$ \\
\hline $\begin{array}{l}\text { Akademi } \\
1971\end{array}$ & çok iyi & çok yoğun & var & var & var & $\begin{array}{ll}\text { var } & \text { (özel } \\
\text { alan) } & \\
\end{array}$ & var & Öğr + serbest \\
\hline Cherrybean & kötü & yoğun & var & var & var & $\begin{array}{l}\text { var (genel } \\
\text { alan) }\end{array}$ & yok & Öğr + serbest \\
\hline Page & iyi & çok yoğun & var & var & var & $\begin{array}{l}\text { var (genel } \\
\text { alan) }\end{array}$ & yok & Öğr + serbest \\
\hline $\begin{array}{l}\text { Tasarım } \\
\text { Bookshop }\end{array}$ & çok iyi & sakin & var & var & var & $\begin{array}{l}\text { var (genel } \\
\text { alan) }\end{array}$ & var & Öğr + serbest \\
\hline Starbucks & iyi & çok yoğun & var & yok & var & $\begin{array}{l}\text { var (genel } \\
\text { alan) }\end{array}$ & yok & Öğr + serbest \\
\hline Dem & çok iyi & çok yoğun & var & yok & var & $\begin{array}{ll}\text { var } & \text { (özel } \\
\text { alan) } & \\
\end{array}$ & yok & Öğr + serbest \\
\hline Han & iyi & sakin & yok & var & var & $\begin{array}{ll}\text { var } & \text { (özel } \\
\text { alan) } & \\
\end{array}$ & yok & Öğr + serbest \\
\hline Dandin & çok iyi & sakin & yok & yok & var & $\begin{array}{l}\text { var } \\
\text { alan) }\end{array}$ & yok & $\begin{array}{l}\text { ser.+beyaz } \\
\text { yakalı }\end{array}$ \\
\hline Fillbooks & çok iyi & çok yoğun & var & var & var & $\begin{array}{l}\text { var } \\
\text { alan) }\end{array}$ & var & Öğr + serbest \\
\hline
\end{tabular}

Çalışmada ele alınan dokuz adet kafe yerinde gözlem, görüşme ve anket yöntemlerinden yararlanılarak analiz edilmiş ve "kafede çalışma" bağlamında şu sonuçlara ulaşılmıştır;

\subsection{Kullanıcı Profili}

Toplamda 75 kişiye uygulanan anketin sonuçlarına bakıldığında, kafeleri çalışmak amacıyla çoğunlukla öğrenciler kullanıyorsa da, özellikle son yıllarda yeni mezunlar, serbest çalışanlar ve kurumsal ancak belirli bir yere bağlı olmadan hareketli biçimde çalışan bireylerin de yoğun olarak kullandıkları görülmüştür (Çizelge 1). Genellikle 2025 yaş arası üniversite öğrencileri ya da yeni mezunlar olan kullanıcıların ağırlıklı olarak bekâr ve çocuksuz kimseler oldukları anket çalışmasıyla tespit edilmiştir (Çizelge 2-3). Tasarım Bookshop, Han ve Dandin Kafe örneklerinin kullanıcı profilinin 
diğer örneklere kıyasla nispeten çok özel bir kitle olduğu ve bu nedenle özellikle hafta içi daha sakin mekânlar oldukları tespit edilmiştir.

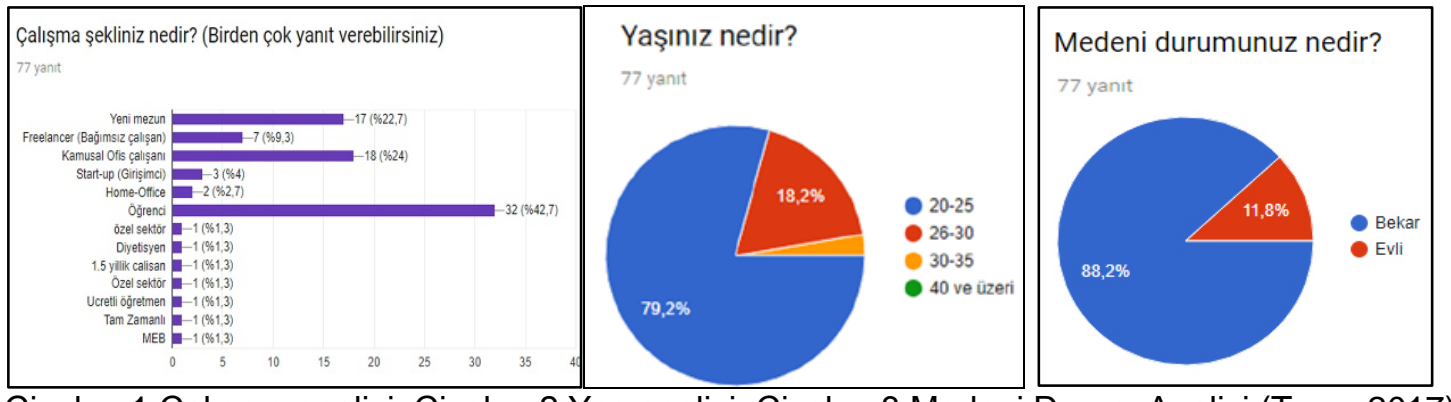

Çizelge 1.Çalışma analizi, Çizelge 2.Yaş analizi, Çizelge 3.Medeni Durum Analizi (Tunç, 2017)

\subsection{Kullanıcı İhtiyaçları}

Bir insanın çalışırken intiyaç duyduğu bir takım temel ve psikolojik gereksinimler sözkonusudur. Fizyolojik, güvenlik, toplumsal vb. başlıklar altında özetlenebilecek bu insani gereksinimler, ortak çalışma biçiminde kalabalık grupların tek mekânı etkin kullanabilmesi, çalışmanın verimli olabilmesi ve bu tip çalışma biçiminin sosyal getirilerinin de yüksek olabilmesi sözkonusu olduğunda üst düzey boyutlarda önem kazanır. Özellikle kafeler için bu gereksinimlerin belli başıları şunlardır:

- Çalışırken yeme-içme intiyacının giderilebilmesi,

- Çalışırken ve dinlenirken kişisel eşyaların, park edilen taşıtın güvenliğinin sağlanması,

- Toplumsal intiyaçları giderecek bütünleşme olanakları,

- Çalışma masalarının ergonomik olması,

- İstenildiğinde aynı masa-sandalyeyi kullanabilme imkânı / aidiyet intiyacı,

- Mekândaki gürültü düzeyinin çalışma eylemini engellemeyecek düzeyde olması,

- Günlük temizlik intiyacının giderilmesi

\subsection{Kafelerin Mimari Tasarımlarının Çalışma Alanı Olarak Sunduğu Olanaklar}

Çalışma kapsamında yapılan gözlem ve anketlere dayanılarak, kafelerin sosyalleşme ve yeme-içme odaklı kamusal kurguları sebebiyle yeni nesil ortak çalışma biçimi için mimari tasarım ve mekân kalitesi açısından kullanıcı intiyaçlarına tam anlamıyla cevap veremedikleri görülmüştür. Buna rağmen kullanıcılar ve mekân sahipleri var olan plan düzlemlerini bu yönde revize etmeye yönelmekte ve bu yeni eğilimin getirdiği kullanıcıyı mekâna çekmeye çalışmaktadırlar. İncelenen kafelerden anlaşılmaktadır ki, kitap okuma eyleminin beraberinde getirdiği sessizlik ve mahremiyet mekânlara da yansıdığından, genelde kitap-kafe konseptli mekânlar bu tarz bir çalışma işlevini barındıran mekânlar olmaya daha yatkındırlar. Kitap-kafe konseptli mekânlar grup aktivitesi olduğunda ortak çalışma alanına, bireysel çalışmaya intiyaç duyulduğunda sabit tekil masa düzenine, gerektiğinde de çok amaçlı etkinlik mekânlarına dönüştürülebilecek esneklikte bir düzenlemeye gidebilmektedirler.

Plan şemaları açısından bakıldığında hemen tüm örneklerde 8-10 kişilik ve üzerinde çoklu elektrik bağlantısı olan büyük masaların bireysel çalışacak bireyler için dahil edildiği görülmektedir. Starbucks, Karabatak, Filbooks, Dandin Kafe örneklerinde bireysel ve/veya grup çalışma alanlarının kimi zaman bölücü duvarlarla, kimi zaman kot 
farkı yaratılarak, kimi zamanda bodrum kat ya da asma kat şeklinde genel kullanıcıdan ayrıştırıldığı görülmüştür. Bu tür kafelerde, özellikle standart kullanıcı ile çalışan kullanıcının ayrışabilmesi ve çalışan kullanıcının da zaman zaman küçük molalar için dış mekâna çıkabilmesi nedeniyle dış mekân kullanımının olması bir artı değer sunmaktadır.

\section{Sonuç}

Kafeleri çalışma amaçlı tercih edenlere uygulanan anket sonucunda yapılan değerlendirmeler şöyledir;

- Bu mekânlar öğrencilere çalışmak için 09.00-17.00 arası yeterli gelse de, çalışanlar için bu zaman aralığı yeterli olmamaktadır. 7/24 hizmet veren bir kafe olmadığı için her an çalışması gerekebilen kimseler için bu zaman aralığı yeterli değildir (Çizelge 4).

- Kafelerde çalışmak için çoğunlukla bireysel kullanım alanlarının tercih edilmesi nedeniyle, kafedeki sosyal etkileşimin çalışma verimini olumsuz yönde etkileyeceğini düşünmek doğaldır. Fakat kullanıcılarla gerçekleştirilen görüşmelerde ve anket sonuçlarında çalışma ortamındaki gürültü ve ışığın çalışanları rahatsız etmediği, aksine bu dinamik ortamın motive edici olduğu yoğun biçimde ifade edilmiştir. Bu nedenle ortak ve bireysel çalışma alanları kullanıcının seçimi ve esnekliğiyle doğru orantılı olmalıdır (Çizelge 5).

- Çalışmada ele alınan kafelerin kullanıcıları eşyalarını ve arabalarını gönül rahatlığıyla emanet edemediklerini belirtmişlerdir. Bu da temel insani bir ihtiyaç olan güvenlik gereksiniminde eksiklik yaratmaktadır (Çizelge 6).

- Kullanıcılar işleri uzun sürdüğünde çalışmaya devam etmek için sürekli yiyecek içecek sipariş etmek zorunda kalmakta, bu durum da bütçelerini zorlayabilmektedir (Çizelge 7).

- Aynı masa ve sandalyeyi kullanamama sorunu aidiyet hissini zayıflatmakta, ancak aynı büyük masanın etrafında yer bulabilme şansı bu olumsuzluğu büyük ölçüde giderebilmektedir.

- Bu çalışma ortamının yaratıcılık ve çalışma motivasyonunu artırıp artırmadığı sorusu karşısında \% 28 oranında kararsızlık hakimken yine \%28 oranında arttırdığı ifade edilmiştir. Bu oranlar kafelerin günümüzde çalışma amaçlı kullanımlarının yoğunlaşmasına karşın, ortak çalışma alanı olarak yeterli gelmediğini ortaya koymaktadır (Çizelge 8).

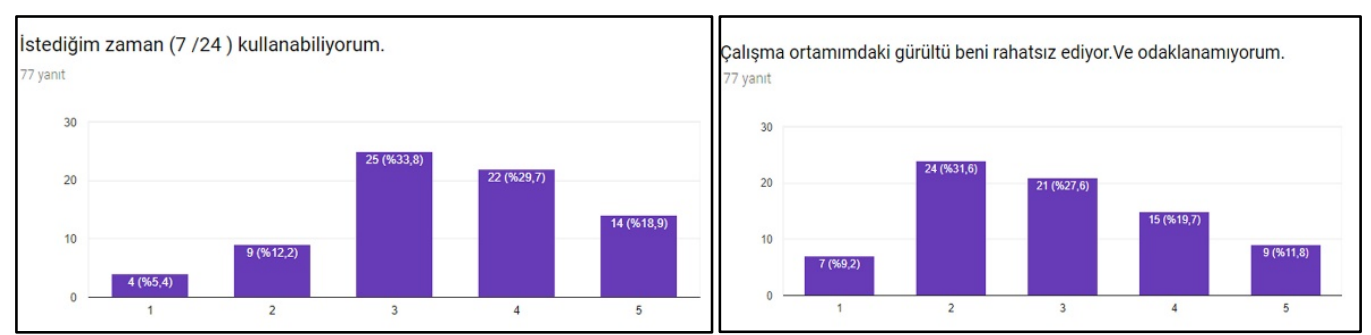

Çizelge 4. Kafelerin Kullanım Analizi, Çizelge 5.Gürültünün Kullanıcılar Üzerindeki Etkisi (Tunç, 2017). 


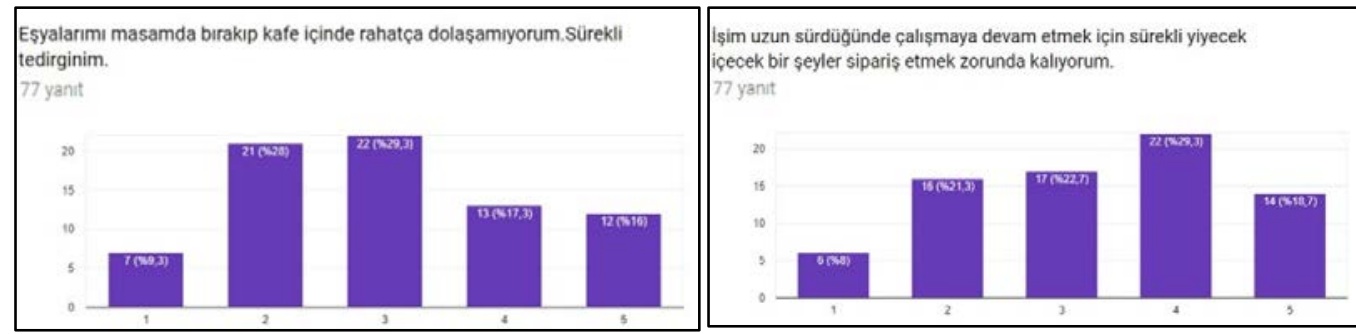

Çizelge 6.Güvenlik Analizi, Çizelge 7.Bütçeyi Zorlayıcı Etkisinin Tespiti (Tunç, 2017).

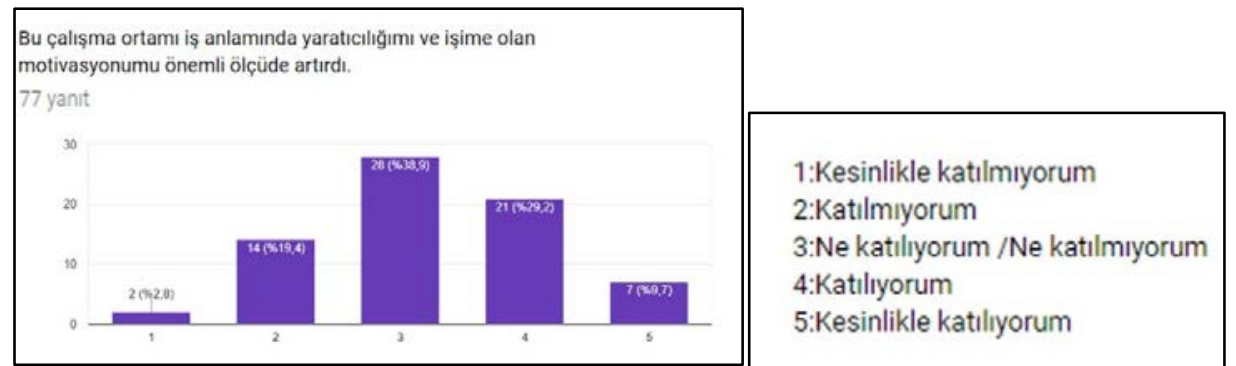

Çizelge 8.Kafelerin Yaratıcılığa ve Motivasyon Üzerindeki Etkisinin Analizi (Tunç, 2017).

Sonuç olarak, yer ve zamandan bağımsız çalışma şansı olan bireylerin kafeleri çalışmak için tercih etmelerinin en önemli nedeni, sosyal hayattan izole bir çalışma hayatını tercih etmemeleridir. Sosyal hayattan kopuk ve izole biçimde evde çalışmaya alternatif olabilen bu esnek mekânlar, sundukları dinamizm ve etkileşim ortamı için tercih edilir hale gelmiştir. Kafelerin bu intiyaçlara tam anlamıyla ve etkili bir şekilde yetememesi sonucunda yurt dışında ve son yıllarda ülkemizde ortaya çıkan paylaşımlı ofisler ortak çalışma kültürüne oldukça kapsayıcı bir şekilde ev sahipliği yapmaktadır. Görülmektedir ki yeni nesil çalışma biçimleri insanların intiyaçlarından doğmakta ve bu intiyaçlar, talepler de varolan çalışma mekânlarını evrimleştirmekte hatta yeni mekânlar oluşturmaktadır. Devamlı olarak çağa ayak uyduran çalışma mekânları dünden bugüne değişmeye ve dönüşmeye devam etmektedir, edecektir. 


\section{Kaynaklar}

TUIK, 2018, http://www.tuik.gov.tr/PreHaberBultenleri.do?id=27587 (Erişim Tarihi:

12.09.2018, 14.00)

Selman, H., 2016, “Co-Working Kültürünün Kısa Tarihi”, http://iyicalisanlarulkesi.com/co-working-kulturunun-kisa-tarihi/ (Erişim Tarihi: 12.09.2018, 14.00)

Foertsch, C., 2011. "The Coworker's Profile" http://www.deskmag.com/en/thecoworkers-global-coworking-survey-168 (Erişim Tarihi: 12.09.2018, 14.00)

Taylor, J., 11.06.2016 "Coworking Cafes" https://www.freshcup.com/coworking-cafes/ (Erişim Tarihi: 29.10.2018, 00.15)

Sundsted, T., Jones, D., Bacigalupo, T., 2009, "I'm Outta Here: How Co-Working Is Making the Office Obsolete", NotanMBA Press, ISBN-10: 0982306709.

Zeytun, D., 2014, "Çalışma Alanlarına Yeni Bir Bakış: Co-Working Spaces" http://bigumigu.com/haber/calisma-alanlarina-yeni-bir-bakis-co-working-spaces/ (Erişim Tarihi: 12.09.2018, 14.00)

http://www.coworkcafe.com/ (Erişim Tarihi: 29.10.2018, 00.15)

https://www.freshcup.com/coworking-cafes/ (Erişim Tarihi: 29.10.2018, 00.15)

https://habitat-cowork.com/ (Erişim Tarihi: 29.10.2018, 00.15)

https://www.vervecoffee.com/pages/los-angeles (Erişim Tarihi: 29.10.2018, 00.15)

http://www.halukar.com/portfolio/fil-books/ (Erişim Tarihi: 11.06.2017, 10.00)

https://www.tripadvisor.com.tr/Restaurant Review-g293974-d3591045-Reviews-

Karabatak Cafe-Istanbul.html (Erişim Tarihi: 12.09.2018, 14.00)

Tunç, Büşra, 2017 "Kafeleri çalışma amaçlı kullananlar İçin Bir Anket-Sorular" https://docs.google.com/forms/d/1F95ijz1rTDUD6yNf6pksFXvNJg946CBo32GWeDqml 4E/edit?usp=drive open\&ths=true

Tunç, Büşra, 2017 "Kafeleri çalışma amaçlı kullananlar İçin Bir Anket-Cevaplar" https://docs.google.com/forms/d/1F95ijz1rTDUD6yNf6pksFXvNJg946CBo32GWeDqml 4E/edit\#responses 